\title{
Protective roles of ginseng against bacterial infection
}

\author{
Ye-Ram Kim ${ }^{1}$ and Chul-Su Yang ${ }^{1, *}$ \\ ${ }^{1}$ Department of Molecular and Life Science, Hanyang University, Ansan 15588, S. Korea; Department of Bionanotechnology, Han- \\ yang University, Seoul, 04673, S. Korea. \\ * Corresponding Author: \\ Chul-Su Yang, 55 Hanyangdaehak-ro, Sangnok-gu, Ansan-si, Gyeonggi-do 15588, S. Korea; Phone: 82-31-400-5519. Fax: 82-31-436- \\ 8153; E-mail: chulsuyang@hanyang.ac.kr
}

\begin{abstract}
Ginseng (Panax ginseng Meyer) is a well-known traditional herbal medicine that plays a protective role against microbial attack. Several studies have revealed its anti-cancer, anti-inflammatory, and immune-modulatory effects. Ginseng contains several components that vary according to the year of cultivation and the processing method used, such as heating, drying, and steaming, which induce different degrees of pharmacological activities. This review discusses the antibacterial effects of ginseng against pathogenic bacterial infections. We describe how ginseng regulates pathogenic factors that are harmful to the host and discuss the therapeutic potential of ginseng as a natural antibacterial drug to combat bacterial infectious disease, which is a global public health challenge. The components of ginseng could be novel alternatives to solve the growing problem of antibiotic resistance and toxicity.
\end{abstract}

\author{
doi: 10.15698/mic2018.11.654 \\ Received originally: 09.07.2018; \\ in revised form: 24.08 .2018 , \\ Accepted 24.08.2018, \\ Published 19.09.2018. \\ Keywords Panax ginseng, Ginsenoside, \\ Bacteria, Antibacterial activity. \\ Abbreviations: \\ KRG - Korea Red Ginseng, \\ MIC - minimum inhibitory \\ concentration, \\ MRSA - methicillin-resistant S. aureus, \\ NO - nitric oxide, \\ $P P D$ - protopanaxadiol, \\ $P P T$ - protopanaxatriol, \\ $Q S$ - quorum sensing, \\ $R G E$ - red ginseng extract, \\ SWE - subcritical water extraction, \\ $T L R$ - toll-like receptor, \\ WGE - white ginseng extract.
}

\section{INTRODUCTION}

Because Asia has a specific topography and soil that differs from that of other continents, it provides unique environmental conditions that support the growth of several medicinal plants, which have been used as agricultural products, food, dietary supplements, health supplements, and medicines [1]. Botanical medication has been used to treat various diseases in Asia for thousands of years. Among these, ginseng (Panax ginseng Meyer, family Araliaceae) is one of the most widely known and used oriental medicinal plants [2]. Ginseng is a shade plant that prefers a cool and dry climate, like that of Korea [1]. The genus "Panax" was named by the Russian botanist Carl Anton Meyer, from the Greek "pan" meaning "all" and "axos" meaning "cure" [1]. The main species of ginseng are $P$. ginseng C.A. Meyer (Korea ginseng), Panax quinquefolius L. (American ginseng), Panax notoginseng Burkill (Tienchi ginseng), and Panax japonicus C.A. Meyer (Japanese ginseng) [3]. By 2009, Ko- rea was the second-highest global producer of ginseng after China [1]. Ginseng is globally distributed throughout 35 countries in various forms following processing via drying, steaming, and heating [2].

Several studies have recently reported the beneficial effects of ginseng on diseases such as cancer; immune disorders; diabetes; and liver, neuronal, cardiovascular, and infectious diseases [4-11]. Although extracts of ginseng root, leaves, and stems exhibit various pharmacological effects, most pharmacologically active compounds are thought to be present in the root, which has been the focus of previous studies. A significant change in the element accumulation occurs during the life cycle of ginseng. $P$. ginseng C.A. Meyer cultivated in Korea is harvested following long cultivation (4-6 years), which allows for the increased composition of secondary metabolites [12]. It is consumed after traditional processing methods, including air drying (white ginseng; after 4-6 years' cultivation), 
steaming and heating (red ginseng; after 6 years' cultivation). Red ginseng is steamed at $98^{\circ} \mathrm{C}-100^{\circ} \mathrm{C}$ for $2-3 \mathrm{~h}$ and then dried at $<15 \%$ humidity. Because the streaming process enhances its biological activity, red ginseng is more widely used as an herbal medicine than white ginseng [1315]. Ginseng contains various bioactive components including tetracyclic triterpenoids (ginsenosides), polyacetylenes, polyphenolic compounds, and acidic polysaccharides of which ginsenoside is highly pharmacologically active.

Although most microorganisms do not induce diseases, some harmful pathogens cause infections in their hosts. When a host is vulnerable to a pathogen, it cannot respond adequately to protect against the infectious disease. Infections are triggered by pathogenic microorganisms, such as bacteria, viruses, parasites, or fungi. The mechanisms of infectious disease development are complex because they depend on interactions between the host, the pathogen, and the environment [16].

Antibiotics are medicines used to prevent and treat bacterial infections. Antibiotic resistance occurs when bacteria change in response to the use of these medicines. Bacteria, not humans or animals, become antibioticresistant. These bacteria may infect humans and animals, and the infections they cause are harder to treat than those caused by non-resistant bacteria. Antibiotic resistance leads to higher medical costs, prolonged hospital stays, and increased mortality. Thus, there is an urgent need to re-think the prescription and use of antibiotics. Even if new medicines are developed, without behavior change, antibiotic resistance will remain a major threat. Behavior changes must also include actions to reduce the spread of infections through vaccination, hand washing, practicing safer sex, and good food hygiene [17-19]. Thus, there is an urgent need to develop novel alternative remedies [20]. The pharmacological effects of natural products, especially the antimicrobial activities of plants, are considered to offer attractive novel treatment strategies. Plants interact with various microorganisms and produce smallmolecule ( $<500 \mathrm{Da}$ ) antimicrobial compounds that limit the harmful effects of pathogenic microorganisms. Thus, many hundreds of plants have been widely used as traditional medicines [21]. Additionally, the combination of natural products and antibiotics exerts a synergistic effect against infectious diseases, resulting in an enhanced antibacterial effect on drug-resistant bacteria and reducing the dosage of existing antibiotics, which alleviates their toxicity [22, 23].

Currently, food-related immune system enhancement has attracted attention because of the global emergence of infectious disease epidemics [24]. Infections can cause different phenomena depending on the immune system status of the host. Healthy individuals can defend their bodies against a pathogenic invader and remain asymptomatic, but immunocompromized people could acquire a severe infectious disease from the same pathogen. The size of the immunocompromized population is rising because of increasing longevity, changing nutritive conditions of modern people, and the development of long-term cures for various diseases [25]. With this increase in infectious disease, ginseng could provide an effective antibacterial treatment. Ginseng has been investigated for its effect on various aspects of disease treatment, especially its role in protection against microbial attack. This review focuses on the effect of ginseng against bacterial infection.

\section{THE MAJOR COMPONENT OF GINSENG}

Ginseng comprises saponin and non-saponin constituents. Saponins are glycosides attached to either a saccharide or non-saccharide component (sapogenin and aglycone) (Fig. 1). Ginsenosides refer specifically to ginseng saponins, named to distinguish them from the saponins of other plants. Ginsenosides are specific secondary metabolites of Panax sp. and comprise the major pharmacological component of the ginseng plant. Over 30 ginsenosides have been isolated and identified in raw or processed ginseng. Ginsenosides are classified as dammarane or oleanane type, depending on their aglycone skeleton. Dammaranetype ginsenosides, the dominant ginsenoside, are protopanaxadiols (PPDs), protopanaxatriols (PPTs), or ocotillols. PPD-group saponins comprise ginsenosides Ra1, Ra2, $\mathrm{Ra} 3, \mathrm{Rb} 1, \mathrm{Rb} 2, \mathrm{Rb} 3$, and Rd; quinquenosides R1 and Rs1Rs3; and malonyl ginsenosides Rb1, Rb2, Rc, and Rd. PPTgroup saponins include ginsenosides Re, Rf, Rg1, Rg2, Rh1, and F1 and notoginsenosides R1 and R2. The ocotillolgroup ginsenosides, identified in Panax species such as P. quinquefolius, P. japonicus, and Panax vietnamensis, comprise majonoside R2 and pseudoginsenoside F11. Ginsenoside Ro has only been identified among the oleananegroup saponins and is a minor component of $P$. ginseng [12].

Korean ginseng contains dammarane-type ginsenosides and a unique saponin found in the Panax genus that is nontoxic and displays antibacterial activity against nonhemolytic bacteria. 32 ginsenosides have been isolated from Korea Red Ginseng (KRG), whereas 22, 13, and 14

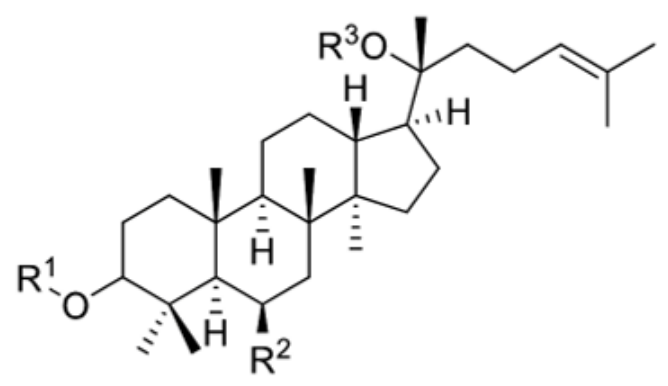

FIGURE 1: General structure of the saponin. Saponins are glucosides with foaming characteristics. Saponins consist of a polycyclic aglycones attached to one or more sugar side chains. The aglycone part, which is also called sapogenin, is either a steroid $\left(\mathrm{C}_{27}\right)$ or a triterpene $\left(\mathrm{C}_{30}\right)$. The foaming ability of saponins is caused by the combination of a hydrophobic (fatsoluble) sapogenin and a hydrophilic (water-soluble) sugar part $\left(R_{1}, R_{2}, R_{3}\right.$ : -sugar or $-H$ group). 
ginsenoside species have been isolated from white ginseng, $P$. quinquefolius, and $P$. notoginseng, respectively [26]. The compound panaxan contains 21 species $\left(R_{0}, R_{1}, R_{2}, R_{a}, R_{b 1}\right.$, $R b 2, R c_{5}, R_{5}, R e, R_{5}, R g l, R g 2, R g 3, R g S_{5} R h l, R h 2, R h 4, R s l$, $R s 2, R s 3_{5}$ or $R_{s 4}$ ), and its principal sugar components include glucose, arabinose, galactose, xylose, and rhamnose [27]. Several studies have revealed that ginseng components other than ginsenosides also possess pharmaceutical properties. For example, the polysaccharide ginsan, isolated from the ginseng root, can induce physiological effects such as cytokine modulation and lymphoid cell stimulation [28].

\section{ANTIBACTERIAL ACTIVITY OF GINSENG}

Microbial infections cause several distinct diseases, requiring different antibiotic treatments, but inappropriate antibiotic usage triggers antibiotic resistance and leads to various toxic side effects in the host [29]. The emergence of multiple-drug-resistant bacteria can render existing antibiotics useless. To address this threat, alternative approaches, such as the use of natural products, have been attempted. This involves targeting bacterial pathways that indirectly kill pathogens and protect the host from bacterial invasions. Such properties have been identified for ginseng [30].

Ginseng indices bactericidal activity, inhibition of DNA mutagenesis, anti-quorum sensing, anti-adhesive activity, inhibition of pathogen-induced hemagglutination, immune-modulatory functions and demonstrates a protective role against pathogen-induced inflammation. The next sections describe the antibacterial effect of ginseng on several representative pathogens (Table 1 and Fig. 2).

\section{Helicobacter pylori}

Helicobacter pylori ( $H$. pylori) is a highly motile, Gramnegative, microaerophilic bacterium that can infect the stomach, impacting human health [31]. H. pylori infects $50 \%$ of the world's population. Most infections are asymptomatic, but some people demonstrate an improper response to the pathogenesis of $H$. pylori, developing peptic ulcers, gastric cancer, or malignant lymphoma [32]. H. pylori colonizes the epithelial surfaces of the stomach mucosa in individuals with active chronic gastritis.

The adhesion of pathogenic bacteria to host cells is crucial to initiate host infection, allowing entry into cells beyond the host barrier and subsequent pathogen multiplication [33]. Recent research has shown that ginseng extract inhibits cell adhesion, thereby blocking the initiation of pathogenic infections. Pectin-type polysaccharide PG-F2 isolated from $P$. ginseng possesses a marked antiadhesion activity against many microbes [34]. Furthermore, ginseng protects against pathogen-induced DNA damage and regulates cell death, as observed in H. pylori infection.

As $H$. pylori induces gastric inflammation, ulceration, and DNA damage, it has been defined as a class I carcinogen by the WHO. H. pylori is the most extensively studied and well-known pathogen which is affected by ginseng via various pathways. Acidic polysaccharides from the roots of
P. ginseng C.A. Meyer (Araliaceae) and the leaves of Artemisia capillaris (Asteraceae) exert anti-adhesive effects on H. pylori infecting human gastric cells and erythrocytes [3537]. In recent studies, fermented ginseng extracts, containing the lactic acid bacterium Lactobacillus plantarum MG 208, exhibited powerful anti- $H$. pylori activity, including anti-bacterial, anti-adhesion, and urease inhibition effects. This extract contained a larger concentration of Rd and R1 ginsenosides compared with other fermented ginseng extracts, which explains its stronger antibacterial activities [38].

Other studies have demonstrated that red ginseng extract (RGE) exerts a protective effect against cytotoxicity and DNA mutagenesis induced by $\mathrm{H}$. pylori and can reduce proinflammatory activity in gastric mucosal cells. An RGE pretreatment of $<100 \mu \mathrm{g} / \mathrm{mL}$ induces protective effects in gastric epithelium cells. RGE also inhibits DNA damage and apoptosis induced by $H$. pylori by inhibiting ERK1/2 signaling. This reduces caspase- 3 activation and subsequent programmed cell death, consequently diminishing proinflammatory cytokine IL-8 or 5-lipoxygenase mRNA expression [39,40-42]. A study by Bae et al. (2001) revealed the inhibition of $H$. pylori growth by polyacetylenes and PPT isolated from RGEs. Moreover, panaxytriol was shown as partially effective in inhibiting $H$. pylori growth $\left(\mathrm{MIC}_{50}=50 \mu \mathrm{g} / \mathrm{mL}\right.$ ). Ginsenoside Rh1 and PPT can cause minor inhibitory effects on $\mathrm{H}^{+} / \mathrm{K}^{+}$ATPases, which are involved in the final step of stomach acid secretion [43]. In an animal model using Mongolian gerbils, RGE showed inhibitory effects on $H$. pylori-induced inflammation. One week after infection with H. pylori via intra-gastric inoculation, the control diet gerbil group was compared with gerbils given a diet containing $200 \mathrm{mg}$ RGE for 6 weeks. Although the RGE diet supplementation did not affect the viable $H$. pylori count in the stomach, RGE inhibited induction of inflammatory mediators (KC, IL-1 $\beta$, iNOS, MOP activity, and LPO level) in the gastric mucosa of the gerbils [44].

White ginseng extract (WGE) has also demonstrated anti- $H$. pylori activity, cytotoxicity, and anti-inflammatory activity in vitro. The antibacterial activity of WGE against $H$. pylori was measured using a disk diffusion assay, and it was concluded that the growth inhibition was dependent on the WGE dosage. Additionally, WGE exerts a cytotoxic effect on various human cancer cell lines such as A-549 (human lung carcinoma), HEC-1-B (human endometrial adenocarcinoma), and HeLa (human uterine adenocarcinoma), but not normal cells. Also, an analysis of antiinflammatory activity using RAW 264.7 cells showed a reduction of nitric oxide (NO) production by WGE treatment [45].

\section{Pseudomonas aeruginosa}

Pseudomonas aeruginosa ( $P$. aeruginosa) is a common environmental Gram-negative, rod-shaped bacterium that is an opportunistic bacillus. $P$. aeruginosa can colonize under various conditions by utilizing many environmental compounds as energy sources [46]. Infections are common in individuals with cystic fibrosis, thermal injury, chronic wounds, chronic obstructive lung diseases, and urinary 


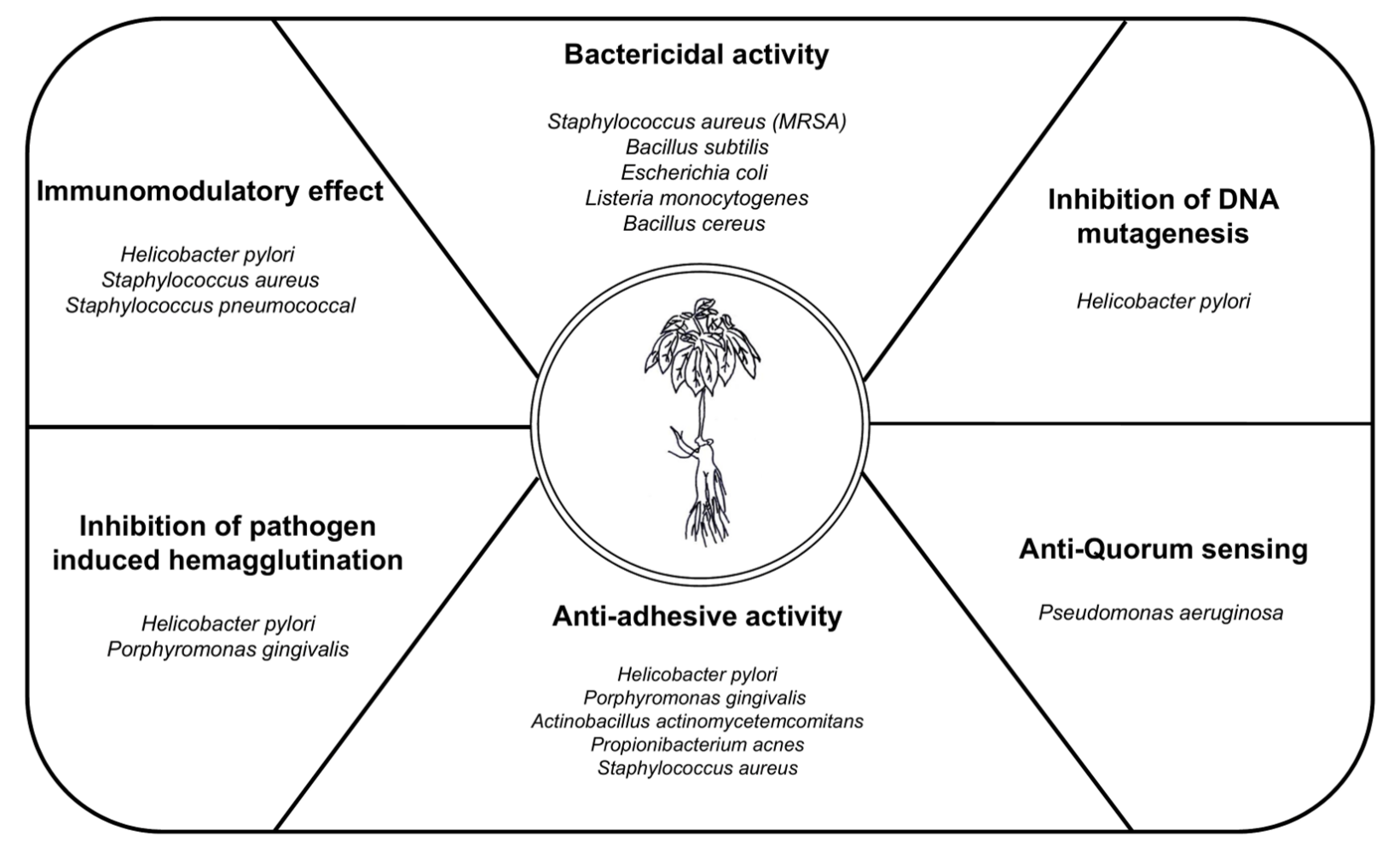

Figure 2: The main types of antibacterial activities of Panax ginseng. $P$. ginseng shows various antibacterial activities against infectious agents. $P$. ginseng convers antimicrobial therapy via various mechanisms, including bactericidal activity, immunomodulatory effects, inhibition of pathogen-induced hemagglutination, anti-adhesive activity, and anti-quorum sensing activity.

tract infections, and in immunocompromized patients with acquired immune deficiency syndrome (AIDS) and AIDSrelated complex [39, 47-49]. Because $P$. aeruginosa can form biofilms, treatment with antibiotics or via the host immune system is challenging. Thus, $P$. aeruginosa has acquired resistance to many antibiotics [50], and therapeutics directly targeting biofilms are required to eliminate $P$. aeruginosa infection. In a 2011 study, Hong et al. showed that although aqueous ginseng extract did not directly affect the growth of $P$. aeruginosa, it reduced biofilm formation in vitro [51].

Some pathogenic bacteria use quorum sensing (QS), a cell-to-cell communication mechanism, during the infectious process. QS responds to changes in cell-population density and regulates gene expression systems, and is crucial for establishing an infection. Through QS, bacteria produce and release signaling molecules called autoinducers that affect bacterial behavior based on cell density. Bacteria present in biofilms, surface-attached groups of microbial cells enveloped in an extracellular matrix, communicate with others in the biofilm by synthesizing and reacting to these chemical signals [52]. Bacterial biofilms can cause chronic infections by limiting the effectiveness of antibiotics. Thus, biofilm reduction is vital in infectious disease treatment. Susceptibility tests with in vitro biofilm models have demonstrated that antibiotics are only effective against bacterial biofilms at concentrations hundreds or even a thousand times the minimum inhibitory concentra- tion (MIC) measured in suspension culture [53, 54]. Ginseng has demonstrated anti-QS activity by suppressing the efficacy of virulence factor production which is related to QS control [53] and inhibition of biofilm formation [39]. Recent research has revealed that $Q S$ in $P$. aeruginosa is required for biofilm formation [52]. $P$. aeruginosa pathogenesis is related to QS through the formation of various extracellular virulence factors and biofilms. Therefore, QS could be a novel target for the treatment of $P$. aeruginosa infections. A 6-year-old dried form of ginseng reduced the levels of QS signaling molecules such as N-butanoyl-Lhomoserine lactone and N-3-(oxododecanoyl)-Lhomoserine lactone. These signaling molecules are critical components that induce the production of virulence factors [53]. A motility test has demonstrated that ginseng activated swimming and twitching motilities but reduced swarming motility, which is essential for biofilm development [51]. The effect of ginseng treatment on $P$. aeruginosa pneumonia in an animal model promoted a Th1-like response, which might activate the phagocytes and NK (natural killer) cells, leading to improved bacterial clearance in the lungs which results in a reduced severity of lung pathology and an easier control of the bacterial infection $[55,56]$.

\section{Staphylococcus aureus}

Staphylococcus aureus (S. aureus) is a Gram-positive commensal bacterium and major pathogen that can trigger 
severe clinical infections. It is widely distributed globally and is strongly resistant to the natural environment. S. aureus colonizes one-third of the human population and commonly exists on the skin and nasal surfaces of healthy people. This bacterium can colonize nares, skin, and the respiratory tract and invade the skin, tissue, and the bloodstream. When $S$. aureus infects the skin, it causes abscesses, sinusitis, and food poisoning. Following bloodstream invasion, S. aureus replicates and disseminates throughout the body, triggering severe infections such as sepsis and endocarditis [57]. S. aureus is able to build biofilms and is a major antibiotic-resistant pathogen. Therefore, the treatment of S. aureus infections is critical. Although the development of new antibiotics is progressing, S. aureus acquires effective resistant mechanisms to antibiotics at a rapid rate. Antibiotic-resistant $S$. aureus includes two types, namely, methicillin and vancomycin resistant strains. Methicillin-resistant S. aureus (MRSA) is resistant to methicillin and other beta-lactam antibiotics, including cephalosporin, ampicillin, and nafcillin, and to almost all antibiotics, which makes treatment of $S$. aureus-infected patients complicated [58, 59]. Ginsenoside extracted from KRG, with an $\mathrm{MIC}_{50}$ of $100 \mu \mathrm{g} / \mathrm{mL}$, has shown antibacterial activity against Gram-positive and Gram-negative bacteria including MRSA and exhibits a similar killing effect as propionic acid, which is a well-known bactericidal agent against MRSA. To identify the antibacterial activity of ginsenoside, a bacterial membrane mimic liposome containing fluorescent marker was used. Treatment with ginsenosides induced the acceleration of fluorescent dye leakage, indicating that ginsenoside disturbs bacterial membranes, thereby causing an antibacterial effect. Combination therapies of antibiotics with ginsenoside have been employed to expand the usage of antibiotics and to prevent the development of resistant strains. The combined effect of ginsenosides and the commercial antibiotics kanamycin and cefotaxime against MRSA has been investigated, and it was concluded that these combinations exerted a synergistic effect against MRSA [60].

Ginsan, a polysaccharide isolated from $P$. ginseng, has induced increased NO production and potent phagocytic activity by macrophages. Ginsan stimulation of the macrophages has enhanced anti-septicemic activity and increased the production of proinflammatory cytokines. Additionally, ginsan treatment has increased proinflammatory cytokine production in the murine fibroblast cell line L929 [61]. Furthermore, Ginsan has demonstrated antisepticemic activity in mouse models. Ginsan has enhanced survival rates and reduced bacterial burden in the blood during S. aureus-infected sepsis in mice. Moreover, a combination of ginsan and vancomycin induced higher protective effects than the respective single treatments, as measured by mice survival rates [61-63]. These results suggest that ginsan possesses a potent anti-septicemic activity by stimulating macrophages and acting as an immunomodulator against sepsis caused by $S$. aureus infections in vitro and in vivo.

The underlying mechanisms of ginsan include its antiseptic activity, affecting the toll-like receptor (TLR) path- way. Ginsan treatment has been shown to reduce proinflammatory and anti-inflammatory cytokine production in S. aureus-infected mice, and ginsan treatment of peritoneal macrophages stimulated by $S$. aureus has suppressed the expression of TLR2, TLR4, TLR9, and the adaptor protein myeloid differentiation primary response 88 . Ginsan has also inhibited mitogen-activated protein kinase signaling and NF-KB activation induced by S. aureus [62-64].

The processing of ginseng using heat transforms its components and has been shown to enhance its antibacterial activity against $S$. aureus. The potent antimicrobial compound Rg3, an absent ginsenoside in non-heated ginseng, is produced by heating ginseng at $100^{\circ} \mathrm{C}$ for $16 \mathrm{~h}$ and exhibits a higher antimicrobial activity via a reduction in the cell membrane potential [65].

\section{Porphyromonas gingivalis}

Porphyromonas gingivalis ( $P$. gingivalis) is a Gram-negative, rod-shaped, non-motile, anaerobic, and pathogenic bacterium. It causes periodontal diseases and colonizes the periodontal pocket, gastrointestinal tract, respiratory tract, and colon. This pathogen induces aggressive inflammation which destroys the gingiva supporting the teeth and eventually leads to tooth loss. $P$. gingivalis rapidly adheres to and enters host cells to induce proinflammatory cytokines such as IL-1 $\beta$ and IL-6 [66]. PG-HMW and PG-F2, acidic polysaccharides isolated from the roots of $P$. ginseng, have been shown to inhibit the attachment of $P$. gingivalis to human oral adenocarcinoma cells such as KB cells [34]. Furthermore, PG-F2 has been shown to inhibit $P$. gingivalismediated hemagglutination. These results suggest that PGF2 could be developed as the base of a dietary component or as a novel anti-adhesive drug for protection against periodontal diseases $[67,68]$. Additionally, steaming of the American ginseng leaf has been shown to induce conversion from polar ginsenosides to less polar ginsenosides. These heat-transformed saponins easily disturbed cell integrity and exhibited higher antibacterial activity than unprocessed saponins against $P$. gingivalis [69].

\section{Listeria monocytogenes}

Listeria monocytogenes (L. monocytogenes) is a facultative pathogenic bacterium that induces listeriosis. It is a small rod-shaped, Gram-positive, facultatively anaerobic bacterium and the most recognized globally virulent intracellular food-borne pathogen. Approximately $20 \%-30 \%$ of foodborne listeriosis is fatal. It is assumed that Listeria triggers 1,600 illnesses in the United States annually, of which 400500 are fatal [70].

Several procedures have been utilized to extract functional components from ginseng, primarily by using different solvents, such as methanol, ethanol and water [71, 72]. In a study in 2012, Choi et al. showed that a water extract of KRG has demonstrated antibacterial activity against $L$. monocytogenes $\left(\mathrm{MIC}_{50}=1.0 \mathrm{mg} / \mathrm{mL}\right.$ ) but not with an ethanol extract [71]. Furthermore, Lee et al. showed that ginseng extracts produced from ginseng byproducts, such as stems and leaves, using subcritical water extraction (SWE) have exhibited anti-L. monocytogenes activity. SWE at a 
TABLE 1. Summary of the ginseng effects on bacterial infection.

\begin{tabular}{|c|c|c|c|c|}
\hline Microbe & Reagent & Effect & Experimental model & Ref \\
\hline \multirow{6}{*}{ H. pylori } & Polysaccharide fractions & Inhibition of hemagglutination & $\begin{array}{l}\text { Measurement of hemagglutinating activities, } \\
\text { enzyme-linked glacosorbent method in vitro }\end{array}$ & [35-37] \\
\hline & $\begin{array}{l}\text { Fermented ginseng } \\
\text { extract containing } \\
\text { L. plantarum MG } 208\end{array}$ & $\begin{array}{l}\text { Inhibition of cell adhesion, growth and ure- } \\
\text { ase activity }\end{array}$ & $\begin{array}{l}\text { Formation of clear zones, measurement of } \\
\text { urease activity and cell adhesion activity in } \\
\text { vitro }\end{array}$ & [38] \\
\hline & \multirow{3}{*}{ RGE } & $\begin{array}{l}\text { Protective activity against proinflammatory } \\
\text { effects in AGS cells }\end{array}$ & $\begin{array}{l}\text { Analysis of cell viability (trypan blue dye exclu- } \\
\text { sion assay, DNA fragmentation assay (comet } \\
\text { assay)) } \\
\text { Measurement of cytokine level, cell signaling } \\
\text { (in vitro) }\end{array}$ & [40] \\
\hline & & $\begin{array}{l}\text { Polyacetylenes and protopanaxatriol, com- } \\
\text { pounds isolated from RGE inhibit growth in } \\
\text { vitro } \\
\text { Gineoside Rh1 and protopanaxatriol inhibit } \\
\mathrm{H}^{+} / \mathrm{K}^{+} \text {ATPase }\end{array}$ & $\begin{array}{l}\text { Determination of MICs, } \\
\text { Rat gastric } \mathrm{H}^{+} / \mathrm{K}^{+} \text {ATPase activity }\end{array}$ & [43] \\
\hline & & Suppresses inflammatory mediators & $\begin{array}{l}\text { Diet with RGE ( } 200 \text { mg for } 6 \text { weeks) in Mongo- } \\
\text { lian gerbils }\end{array}$ & [44] \\
\hline & WGE & anti-H. pylori activity in vitro & Disc diffusion assay & {$[45]$} \\
\hline \multirow{4}{*}{ P. aeruginosa } & $\begin{array}{l}\text { Ginseng aqueous ex- } \\
\text { tract }\end{array}$ & $\begin{array}{l}\text { Effect on motility } \\
\text { Inhibition of biofilm formation }\end{array}$ & $\begin{array}{l}\text { Motility assays (swimming, twitching motility, } \\
\text { swarming), } \\
\text { Observation of biofilm formation (confocal } \\
\text { laser scanning microscopy) }\end{array}$ & {$[51]$} \\
\hline & \multirow[b]{3}{*}{ Dried ginseng } & Anti-QS activity & $\begin{array}{l}\text { Detection of alginate levels, protease activities, } \\
\text { BHL, OdDHL, extracellular proteins }\end{array}$ & [53] \\
\hline & & $\begin{array}{l}\text { Enhanced Th1 like response, reduced bacte- } \\
\text { rial load in lungs and reduced severity of lung } \\
\text { pathology in rats }\end{array}$ & $\begin{array}{l}\text { Effects of ginseng treatment in a rat model } \\
\text { Measurement of degree of lung pathology in a } \\
\text { mouse model (cytokine level, mortality, CFU, } \\
\text { histopathology) }\end{array}$ & [55] \\
\hline & & $\begin{array}{l}\text { Cytokine modulating effect in a mouse mod- } \\
\text { el of } P \text {. aeruginosa lung infection }\end{array}$ & $\begin{array}{l}\text { CBA/J mice infected } P \text {. aeruginosa mimics } \\
\text { cystic fibrosis patients. } \\
\text { Measurement of ginseng effects on degree of } \\
\text { severity in a mouse model (cytokine level, } \\
\text { mortality, CFU, histopathology) }\end{array}$ & [56] \\
\hline \multirow[b]{2}{*}{ S. aureus } & KRG & $\begin{array}{l}\text { Antibacterial activity in vitro }\left(\mathrm{MIC}_{50}=100\right. \\
\mu \mathrm{g} / \mathrm{mL} \text { ), Ginsenoside of } \mathrm{KRG} \text { triggers pertur- } \\
\text { bation of plasma membrane }\end{array}$ & $\begin{array}{l}\text { Antibacterial activity assay, } \\
\text { Fluorescent marker calcein leakage measure- } \\
\text { ment from liposomes }\end{array}$ & {$[60]$} \\
\hline & Ginsan & $\begin{array}{l}\text { Polysaccharide showed anti-septic effects, } \\
\text { Ginsan enhanced proinflammatory abilities } \\
\text { (NO, proinflammatory cytokine production, } \\
\text { phagocytic activity of macrophages). } \\
\text { Ginsan modulated TLR pathway }\end{array}$ & $\begin{array}{l}\text { Measurement of survival rate, NO, phagocytic } \\
\text { activity, proinflammatory cytokine, CFU in } \\
\text { C57/BL6 mice. } \\
\text { Analysis of } S \text {. aureus induced protein- } \\
\text { expression, such as TLR, MAPK, NK-KB activa- } \\
\text { tion in peritoneal macrophage }\end{array}$ & {$[61,77]$} \\
\hline \multirow[t]{2}{*}{ P. gingivalis } & Polysaccharide & $\begin{array}{l}\text { Anti-adhesive activity and anti- } \\
\text { hemagglutination }\end{array}$ & Determination of MIC & {$[67,68]$} \\
\hline & $\begin{array}{l}\text { Heat transformed gin- } \\
\text { senoside }\end{array}$ & $\begin{array}{l}\text { Antibacterial activity by damaging bacterial } \\
\text { cell membrane integrity }\end{array}$ & Determination of MIC, cell integrity & [69] \\
\hline \multirow{2}{*}{$\begin{array}{l}\text { L. monocyto- } \\
\text { genes }\end{array}$} & $\begin{array}{l}\text { Ginseng extracts from } \\
\text { stems and leaves }\end{array}$ & $\begin{array}{l}\text { Antibacterial activity by damaging bacterial } \\
\text { cell membrane integrity }\end{array}$ & $\begin{array}{l}\text { Determination of MIC by agar well diffusion } \\
\text { assay } \\
\text { cell integrity by TEM }\end{array}$ & [72] \\
\hline & KRG & Antimicrobial activity & $\begin{array}{l}\text { Paper disc methods } \\
\text { Determination of MIC }\end{array}$ & [71] \\
\hline \multirow{3}{*}{ B. cereus } & KRG & Antimicrobial activity & $\begin{array}{l}\text { Paper disc methods } \\
\text { Determination of MIC }\end{array}$ & [71] \\
\hline & Fine ginseng root & Antimicrobial activity & Disc diffusion method & [75] \\
\hline & Heated ginseng extract & Antimicrobial activity & $\begin{array}{l}\text { Disc diffusion method } \\
\text { Determination of MIC and MBC }\end{array}$ & [65] \\
\hline S. pneumoniae & KRG & $\begin{array}{l}\text { Antibacterial activity } \\
\text { Protective role against S. pneumoniae- } \\
\text { induced sepsis in vivo } \\
\text { Reduced TLR/NK-KB signaling activity in vitro }\end{array}$ & $\begin{array}{l}\text { Measurement of survival rate, body weight } \\
\text { change, colonizing bacteria }\end{array}$ & [76] \\
\hline
\end{tabular}

Abbreviations: KRG: Korean red ginseng, MBC: minimum bactericidal concentration, MIC: minimum inhibitory concentration, RGE: red ginseng extract, TEM: transmission electron microscopy. 
high temperature enhanced the extraction yield of the phenolic portion in ginseng stems and leaves and also resulted in higher antibacterial activity. Treatment using a $0.2 \%$ of SWE ginseng extract has induced morphological cell damage and the loss of structural integrity of bacterial cell walls. From the results obtained by measuring the leakage of cellular materials through the cytoplasmic membrane during treatment with SWE ginseng extract, it is expected that the antibacterial activity demonstrated against $L$. monocytogenes is induced by disrupting membrane integrity [72].

\section{Bacillus cereus}

Bacillus cereus (B. cereus) is a Gram-positive, sporeforming, facultative anaerobe bacterium. It is arranged in chain patterns and is motile because of a flagellum. This pathogen forms heat-resistant spores and can exist in and poison food. B. cereus is environmentally widespread and has been isolated from soil and plants. It also flourishes in insects and the intestinal tracts of mammals. The bacterium produces many virulence factors, including toxins such as emetic toxin and enterotoxins [73]. These toxins can cause two types of illness: one type characterized by diarrhea and the other, called emetic toxin, by nausea and vomiting. These bacteria are present in foods and can multiply quickly at room temperature. The pathogenicity of $B$. cereus, whether intestinal or non-intestinal, is associated with the production of a tissue-destructive/reactive exoenzyme. Additionally, food poisoning by intestinal infection triggers a systemic and local infection in immunologically compromised and immunocompetent individuals [74]. Treatment with ginseng has been shown to have an antibacterial effect against $B$. cereus [71]. A study has compared the antibacterial activities among extracts of fine ginseng roots with various solvents. The results revealed that the hexane fraction demonstrated the highest antibacterial activity compared with that of the other fractions [75]. Furthermore, the dried stems and leaves of ginseng extract produced by SWE at $190^{\circ} \mathrm{C}$ have demonstrated antibacterial activity against $B$. cereus by causing bacterial cell membrane damage and inhibition of cell growth, as observed using transmission electron microscopy [72]. A recent study has shown that heating ginseng enhanced its antimicrobial activity against $B$. cereus. Ginseng was extracted using methanol and ethanol and processed at various time points. The antimicrobial activity of the heattreated ginseng extracts was measured using a disk diffusion method. The results indicated that the ginseng extract heated to $100^{\circ} \mathrm{C}$ demonstrated the highest antimicrobial activity against $B$. cereus. Changes to the ginsenoside composition and contents via the heating process enhanced the bacterial growth inhibition effect [65].

\section{Staphylococcus pneumoniae}

Streptococcus pneumoniae (S. pneumoniae) is a Grampositive bacterium which is the most common cause of pneumonia, and its infection results in $50 \%$ of sepsis cases. Ginsan has demonstrated antiseptic effects against sepsis induced by S. pneumoniae; a KRG water extract was shown to reduce the severity of pneumococcal sepsis. Upon KRG treatment, mice infected with S. pneumoniae D39 experienced a smaller reduction in body weight and an enhanced survival rate. Additionally, bacterial colonization was reduced, and lung inflammation decreased following treatment with KRG. Moreover, S. pneumonia-mediated TLR/NF-KB activation was inhibited by KRG treatment in vitro in the same manner as for $S$. aureus. KRG increased PI3K-AKT signaling, thereby enhancing cell survival in S. pneumonia-infected RAW 264.7 cells [76, 77].

\section{CONCLUSIONS AND FUTURE PERSPECTIVES}

Several studies have suggested that using ginseng to cure infectious diseases could protect the host against pathogen infection. Ginseng has effects that not only directly kill bacteria but also work against the regulation of bacterial adhesion, inflammation, cytotoxicity, and hemagglutination (Table. 1 and Fig. 2). Although the importance of infectious diseases caused by viruses was recently highlighted, bacterial infections remain the most serious problem. Emerging infectious diseases and antibiotic resistance present an immense global predicament, which is limited by the availability of effective antibacterial agents and vaccines. Additionally, an indiscreet use of antibiotics to solve these infections triggers severe side effects in patients. Because of these problems, natural products like ginseng have been highlighted as treatments for bacterial infection with a verified relatively low toxicity. However, because the causal relationship between specific active components and the bioactivities of ginseng is unclear, additional research is required to understand the use of ginseng as an antimicrobial agent. On the other hand, ginseng research could be applied to the food industry to prevent food poisoning because several food pathogens are affected by the antibacterial activity of ginseng. Additionally, the effect of ginseng byproducts outside the root have largely been ignored, but a recent study has revealed that various portions of ginseng demonstrate biologic effects. Years of cultivation of ginseng are critical because of the accumulation of biologically active ginseng components over time. The processing of ginseng, such as heating, drying, and boiling, transforms these components, enhancing the antibacterial effect of ginseng as shown in some studies. As we have explained, the optimal use of ginseng will require the development of additional studies. Using ginseng as a natural antibiotic could be a powerful way to deal with bacterial infections.

\section{ACKNOWLEDGMENTS}

This work was supported by the National Research Foundation of Korea (NRF) grant funded by the Korea government (MSIP) (No. 2016R1D1A1A02937312). This work was supported by the research fund of Hanyang University (HY-2015-N).

\section{CONFLICT OF INTEREST}

The authors declare that they have no conflict of interest. 


\section{COPYRIGHT}

(C) $2018 \mathrm{Kim}$ and Yang. This is an open-access article released under the terms of the Creative Commons Attribution (CC BY) license, which allows the unrestricted use, distribution, and reproduction in any medium, provided the original author and source are acknowledged.

\section{REFERENCES}

1. Lee OR, Sathiyaraj G, Kim YJ, In JG, Kwon WS, Kim JH, Yang DC (2011). Defense Genes Induced by Pathogens and Abiotic Stresses in Panax Ginseng C. A. Meyer. J Ginseng Res 35(1):1-11. doi: 10.5142/jgr.2011.35.1.001

2. Yun TK (2001). Brief introduction of Panax ginseng C.A. Meyer. J Korean Med Sci 16(Suppl):S3-S5. doi: 10.3346/jkms.2001.16.S.S3

3. Baeg IH, So SH (2013). The world ginseng market and the ginseng (Korea). J Ginseng Res 37(1):1-7. doi: 10.5142/jgr.2013.37.1

4. Helmes S (2004). Cancer Prevention and Therapeutics: Panax Ginseng. Altern Med Rev 9(3):259-275. PMID: 15387718

5. Radad K, Gille G, Liu L, Rausch WD (2006). Use of Ginseng in Medicine With Emphasis on Neurodegenerative Disorders. J Pharmacol Sci 100(3):175-186. PMID: 16518078

6. Benzie IFF, Wachtel-Galor S (2011). Herbal medicine : biomolecular and clinical aspects. Taylor \& Francis Group, Chapter 1:1-11.

7. Yoo DG, Kim MC, Park MK, Song JM, Quan FS, Park KM, Cho YK, Kang SM (2012). Protective Effect of Korean Red Ginseng Extract on the Infections by $\mathrm{H} 1 \mathrm{~N} 1$ and $\mathrm{H} 3 \mathrm{~N} 2$ Influenza Viruses in Mice. J Med Food 15(10):855-862. doi: 10.1089/jmf.2012.0017

8. Im K, Kim J, Min H (2016). Ginseng, the natural effectual antiviral: Protective effects of Korean red ginseng against viral infection. J Ginseng Res 40(4):309-314. doi: 10.1016/j.jgr.2015.09.002

9. Lee J, Ko EJ, Hwang H, Lee YN, Kwon YM, Kim MC, Kang SM (2014). Antiviral activity of ginseng extract against respiratory syncytial virus infection. Int J Mol Med 34(1):183-190. doi: 10.3892/ijmm.2014.1750

10. Kim S, Lee Y, Cho J (2014). Korean Red Ginseng Extract Exhibits Neuroprotective Effects through Inhibition of Apoptotic Cell Death. Biol Pharm Bull 37(6):938-946. PMID: 24882407

11. Vuksan V, Sievenpipper J, Jovanovski E, Jenkins AL (2010). Current clinical evidence for Korean red ginseng in management of diabetes and vascular disease: A Toronto's Ginseng Clinical Testing Program. J Ginseng Res 34(4):264-273. doi: 10.5142/jgr.2010.34.4.264

12. Kim YJ, Zhang D, Yang DC (2015). Biosynthesis and biotechnological production of ginsenosides. Biotechnol Adv 33(6 Pt 1):717-735. doi: 10.1016/j.biotechadv.2015.03.001

13. Kim WY, Kim JM, Han SB, Lee SK, Kim ND, Park MK, Kim CK, Park JH (2000). Steaming of ginseng at high temperature enhances biological activity. J Nat Prod 63(12):1702-1704. PMID: 11141123

14. Wang L, Yang $X, Y u$ X, Yao Y, Ren G (2013). Evaluation of antibacterial and anti-inflammatory activities of less polar ginsenosides produced from polar ginsenosides by heattransformation. J Agric Food Chem 61(50):12274-12282. doi: $10.1021 / \mathrm{jf404461 \textrm {q }}$

15. Lee SA, Jo HK, Im BO, Kim S, Whang WK, Ko SK (2012). Changes in the Contents of Prosapogenin in the Red Ginseng (Panax ginseng) Depending on Steaming Batches. J Ginseng Res 36(1):102-106. doi: 10.5142/jgr.2012.36.1.102

16. Office USGA (2004). Emerging Infectious Diseases: Review of State and Federal Disease Surveillance Efforts. GAO-04-877, pp 1-64.
Please cite this article as: Ye-Ram Kim and Chul-Su Yang (2018). Protective roles of ginseng against bacterial infection. Microbial Cell 5(11): 472-481. doi: 10.15698/mic2018.11.654

17. Morehead MS, Scarbrough C (2018). Emergence of Global Antibiotic Resistance. Prim Care 45(3):467-484. doi: 10.1016/j.pop.2018.05.006

18. Petchiappan A, Chatterji D (2017). Antibiotic Resistance: Current Perspectives. ACS Omega 2(10):7400-7409. doi: 10.1021/acsomega.7b01368

19. Jansen KU, Knirsch C, Anderson AS (2018). The role of vaccines in preventing bacterial antimicrobial resistance. Nat Med 24(1):10-19. doi: $10.1038 / \mathrm{nm} .4465$

20. Davies J, Davies D (2010). Origins and evolution of antibiotic resistance. Microbiol Mol Biol Rev 74(3):417-433. doi: 10.1128/MMBR.00016-10

21. Martin KW, Ernst E (2003). Herbal medicines for treatment of bacterial infections: a review of controlled clinical trials. J Antimicrob Chemother 51(2):241-246. PMID: 12562687

22. Buhner SH (2012). Herbal antibiotics: natural alternatives for treating drug-resistant bacteria. Second edition. Storey Publishing, LLC.

23. Hemaiswarya S, Kruthiventi AK, Doble M (2008). Synergism between natural products and antibiotics against infectious diseases. Phytomedicine 15(8):639-652. doi: 10.1016/j.phymed.2008.06.008

24. Calder PC, Kew S (2002). The immune system: a target for functional foods? Br J Nutr 88(Suppl 2):S165-S176. PMID: 12495459

25. Dye C (2014). After 2015: infectious diseases in a new era of health and development. Philos Trans $\mathbf{R}$ Soc Lond B Biol Sci 369(1645):20130426. doi: 10.1098/rstb.2013.0426

26. Park SY, Kim HB, Kim JH, Lee JM, Kim SR, Shin HS, Yi TH (2014). Immunostimulatory effect of fermented red ginseng in the mouse model. Prev Nutr Food Sci 19(1):10-18. doi: 10.3746/pnf.2014.19.1.010

27. Konno C, Sugiyama K, Kano M, Takahashi M, Hikino H (1984). Isolation and Hypoglycaemic Activity of Panaxans A, B, C, D and E, Glycans of Panax ginseng Roots. Planta Med 50(5):434-436. doi: $10.1055 / s-2007-969757$

28. Kim KH, Lee YS, Jung IS, Park SY, Chung HY, Lee IR, Yun YS (1998). Acidic Polysaccharide from Panax ginseng, Ginsan, Induces Th1 Cell and Macrophage Cytokines and Generates LAK Cells in Synergy with rIL-2. Planta Med 64(2):110-115. doi: 10.1055/s-2006-957385

29. Blair JM, Webber MA, Baylay AJ, Ogbolu DO, Piddock LJ (2015). Molecular mechanisms of antibiotic resistance. Nat Rev Microbiol 13(1):42-51. doi: 10.1038/nrmicro3380

30. Pizarro-Cerdá J, Cossart P (2006). Bacterial Adhesion and Entry into Host Cells. Cell 124(4):715-727. doi: 10.1016/j.cell.2006.02.012

31. Cho YK, Jung Y, Sung H, Joo CH (2011). Frequent Genetic Defects in the HIV-1 5'LTR/gag Gene in Hemophiliacs Treated with Korean Red Ginseng: Decreased Detection of Genetic Defects by Highly Active Antiretroviral Therapy. J Ginseng Res 35(4):413-420. doi: 10.5142/jgr.2011.35.4.413

32. Kawakubo M, Ito Y, Okimura Y, Kobayashi M, Sakura K, Kasama S, Fukuda MN, Fukuda M, Katsuyama T, Nakayama J (2004). Natural 
antibiotic function of a human gastric mucin against Helicobacter pylori infection. Science 305(5686):1003-1006. PMID: 15310903

33. Ribet $D$, Cossar $P$ (2015). How bacterial pathogens colonize their hosts and invade deeper tissues. Microbes Infect 17(3):173-183. doi: 10.1016/j.micinf.2015.01.004

34. Lee JH, Shim JS, Chung MS, Lim ST, Kim KH (2009). Inhibition of pathogen adhesion to host cells by polysaccharides from Panax ginseng. Biosci Biotechnol Biochem 73(1):209-212. doi: 10.1271/bbb. 80555

35. Belogortseva NI, Yoon JY, Kim KH (2000). Inhibition of Helicobacter pylori hemagglutination by polysaccharide fractions from roots of Panax ginseng. Planta Med 66(3):217-220. PMID: 10821045

36. Woo JS, Ha BH, Kim TG, Lim YH, Kim KH (2001). Development of an enzyme-linked glycosorbent method to monitor the inhibition of sialic acid-dependent Helicobacter pylori adhesion. Biotechnol Lett 23(7):507-511. doi: 10.1023/A:1010360412969

37. Lee JH, Eun KP, Uhm CS, Chung MS, Kyung HK (2004). Inhibition of Helicobacter pylori adhesion to human gastric adenocarcinoma epithelial cells by acidic polysaccharides from Artemisia capillaris and Panax ginseng. Planta Med 70(7):615-619. PMID: 15254854

38. Yang JW, Choi SY, Park SJ, Paek NS, Kim SS (2012). AntiHelicobacter Pylori Effect of Fermented Ginseng Extracts with Lactobacillus plantarum MG 208. J Korean Soc Appl Biol Chem 55(1):53-56. doi: 10.1007/s13765-012-0009-0

39. Wu H, Høiby N, Yang L, Givskov M, Song Z (2014). Effects of Radix Ginseng on microbial infections: a narrative review. J Tradit Chinese Med 34(2):227-233. doi: 10.1016/s0254-6272(14)60083-2

40. Park S, Yeo M, Jin JH, Lee KM, Jung JY, Choue R, Cho SW, Hahm KB (2005). Rescue of Helicobacter pylori-Induced Cytotoxicity by Red Ginseng. Dig Dis Sci 50(7):1218-27.doi: 10.1007/s10620-005-2763-x

41. Park S, Yeo M, Jin JH, Lee KM, Kim SS, Choi SY, Hahm KB (2007). Inhibitory Activities and Attenuated Expressions of 5-LOX with Red Ginseng in Helicobacter pylori-Infected Gastric Epithelial Cells. Dig Dis Sci 52(4):973-982. doi: 10.1007/s10620-006-9440-6

42. Lee SY, Shin YW, Hahm KB (2008). Phytoceuticals: Mighty but ignored weapons against Helicobacter pylori infection. J Dig Dis 9(3):129-139. doi: 10.1111/j.1751-2980.2008.00334.x

43. Bae EA, Han MJ, Baek NL, Kim DH (2001). In Vitro Anti-Helicobacter pylori Activity of Panaxytriol Isolated from Ginseng. Arch Pharm Res 24(4):297-299. PMID: 11534760

44. Bae M, Jang S, Lim JW, Kang J, Bak EJ, Cha JH, Kim H (2014). Protective effect of Korean red ginseng extract against Helicobacter pylori-induced gastric inflammation in Mongolian gerbils. J Ginseng Res 38(1):8-15. doi: 10.1016/j.jgr.2013.11.005

45. Jee HS, Chang KH, Moon SH, Park SH, Paik HD (2008). AntiHelicobacter pylori, Cytotoxic, and Anti-inflammatory Activities of White Ginseng Extract. Food Sci Biotechnol 17(5):1106-1109.

46. Williams PA, Worsey MJ (1976). Ubiquity of plasmids in coding for toluene and xylene metabolism in soil bacteria: evidence for the existence of new TOL plasmids. J Bacteriol 125(3):818-828. PMID: 1254555

47. Franzetti F, Cernuschi M, Esposito R, Moroni M (1992). Pseudomonas infections in patients with AIDS and AIDS-related complex. J Intern Med 231(4):437-443. PMID: 1588272

48. Lyczak J, Cannon C, Pier G (2000). Establishment of Pseudomonas aeruginosa infection: lessons from a versatile opportunist. Microbes Infect 2(9):1051-1060. PMID: 10967285

49. Hyun SH, Kim ES, Lee SM, Kyung JS, Lee SM, Lee JW, Kim MR, Hong JT, Kim YS (2014). Comparative study on immuno-enhancing effects of red ginseng fractions. J Korean Soc Food Sci Nutr 43(11):1665-1673. doi: 10.3746/jkfn.2014.43.11.1665

50. Stewart PS, Costerton JW (2001). Antibiotic resistance of bacteria in biofilms. Lancet 358(9276):135-138. PMID: 11463434

51. Wu H, Lee B, Yang L, Wang H, Givskov M, Molin S, Høiby N, Song Z (2011). Effects of ginseng on Pseudomonas aeruginosa motility and biofilm formation. FEMS Immunol Med Microbiol 62(1):49-52. doi: 10.1111/j.1574-695X.2011.00787.x

52. Miller MB, Bassler BL (2001). Quorum Sensing in Bacteria. Annu Rev Microbiol 55:165-99. doi: 10.1146/annurev.micro.55.1.165

53. Song Z, Kong KF, Wu H, Maricic N, Ramalingam B, Priestap $H$, Schneper L, Quirke JM, Høiby N, Mathee K (2010). Panax ginseng has anti-infective activity against opportunistic pathogen Pseudomonas aeruginosa by inhibiting quorum sensing, a bacterial communication process critical for establishing infection. Phytomedicine 17(13):10401046. doi: 10.1016/j.phymed.2010.03.015

54. Ceri H, Olson ME, Stremick C, Read RR, Morck D, Buret A (1999). The Calgary Biofilm Device: New technology for rapid determination of antibiotic susceptibilities of bacterial biofilms. J Clin Microbiol 37(6):1771-1776. PMID: 10325322

55. Song Z, Krogh Johansen H, Faber V, Moser C, Kharazmi A, Rygaard J, Høiby N (1997). Ginseng Treatment Reduces Bacterial Load and Lung Pathology in Chronic Pseudomonas aeruginosa Pneumonia in Rats. Antimicrob Agents Chemother 41(5):961-964. PMID: 9145852

56. Song Z, Moser C, Wu H, Faber V, Kharazmi A, Høiby N (2003). Cytokine modulating effect of ginseng treatment in a mouse model of Pseudomonas aeruginosa lung infection. J Cyst Fibros 2(3):112-119. doi: 10.1016/S1569-1993(03)00065-1

57. Thomer L, Schneewind O, Missiakas D (2016). Pathogenesis of Staphylococcus aureus Bloodstream Infections. Annu Rev Pathol Mech Dis 11:343-364. doi: 10.1146/annurev-pathol-012615-044351

58. World Health Organization (2014). Antimicrobial resistance: global report on surveillance 2014. World Health Organization, pp 1-257.

59. Lowy FD (2003). Antimicrobial resistance: the example of Staphylococcus aureus. J Clin Invest 111(9):1265-1273. doi: 10.1172/JCl18535

60. Sung WS, Lee DG (2008). The combination effect of Korean red ginseng saponins with kanamycin and cefotaxime against methicillinresistant Staphylococcus aureus. Biol Pharm Bull 31(8):1614-1617. doi: $10.1248 / \mathrm{bpb} .31 .1614$

61. Lim DS, Bae KG, Jung IS, Kim CH, Yun YS, Song JY (2002). Antisepticaemic effect of polysaccharide from Panax ginseng by macrophage activation. J Infect 45(1):32-38. doi: 10.1053/jinf.2002.1007

62. Ahn JY, Song JY, Yun YS, Jeong G, Choi IS (2006). Protection of Staphylococcus aureus-infected septic mice by suppression of early acute inflammation and enhanced antimicrobial activity by ginsan. FEMS Immunol Med Microbiol 46(2):187-197. doi: 10.1111/j.1574695X.2005.00021.X

63. Kim JH, Yi YS, Kim MY, Cho JY (2017). Role of ginsenosides, the main active components of Panax ginseng, in inflammatory responses and diseases. J Ginseng Res 41(4):435-443. doi: 10.1016/j.jgr.2016.08.004

64. Yang CS, Ko SR, Cho BG, Shin DM, Yuk JM, Li S, Kim JM, Evans RM, Jung JS, Song DK, Jo EK (2008). The ginsenoside metabolite compound $\mathrm{K}$, a novel agonist of glucocorticoid receptor, induces tolerance to endotoxin-induced lethal shock. J Cell Mol Med 12(5A):1739-1753. doi: 10.1111/j.1582-4934.2007.00181.x

65. Na S, Kim JH, Rhee YK, Oh SW (2017). Enhancing the antimicrobial activity of ginseng against Bacillus cereus and Staphylococcus aureus 
by heat treatment. Food Sci Biotechnol 27(1):203-210. doi: 10.1007/s10068-017-0209-9

66. Mysak J, Podzimek S, Sommerova P, Lyuya-Mi Y, Bartova J, Janatova T, Prochazkova J, Duskova J (2014). Porphyromonas gingivalis: major periodontopathic pathogen overview. J Immunol Res 2014:476068. doi: 10.1155/2014/476068

67. Lee JH, Lee JS, Chung MS, Kim KH (2004). In Vitro Anti-Adhesive Activity of an Acidic Polysaccharide from Panax ginseng on Porphyromonas gingivalis Binding to Erythrocytes. Planta Med 70(6):566-569. doi: 10.1055/s-2004-827160

68. Lee JH, Shim JS, Lee JS, Kim MK, Chung MS, Kim KH (2006). Pectinlike acidic polysaccharide from Panax ginseng with selective antiadhesive activity against pathogenic bacteria. Carbohydr Res 341(9):1154-1163. doi: 10.1016/j.carres.2006.03.032

69. Xue P, Yao Y, Yang XS, Feng J, Ren GX (2017). Improved antimicrobial effect of ginseng extract by heat transformation. J Ginseng Res 41(2):180-187. doi: 10.1016/j.jgr.2016.03.002

70. Ramaswamy V, Cresence VM, Rejitha JS, Lekshmi MU, Dharsana KS Prasad SP, Vijila HM (2007). Listeria - review of epidemiology and pathogenesis. J Microbiol Immunol Infect 40(1):4-13. PMID: 17332901

71. Choi YH, Kim SE, Huh J, Han YH, Lee MJ (2012). Antibacterial and Antioxidative Activity of Roasted Coffee and Red Ginseng Mixture Extracts. J Korean Soc Food Sci Nutr 41(3):320-326. doi: 10.3746/jkfn.2012.41.3.320
72. Lee KA, Kim WJ, Kim HJ, Kim KT, Paik HD (2013). Antibacterial activity of Ginseng (Panax ginseng $\mathrm{C}$. A. Meyer) stems-leaves extract produced by subcritical water extraction. Int J Food Sci Technol 48(5):947-953. doi: 10.1111/ijfs.12046

73. Stenfors Arnesen LP, Fagerlund A, Granum PE (2008). From soil to gut: Bacillus cereus and its food poisoning toxins. FEMS Microbiol Rev 32(4):579-606. doi: 10.1111/j.1574-6976.2008.00112.x

74. Bottone EJ (2010). Bacillus cereus, a volatile human pathogen. Clin Microbiol Rev 23(2):382-398. doi: 10.1128/CMR.00073-09

75. Lim JK, Kang HJ, Kang SN, Lee BY (2009). Antioxidant and antimicrobial activities of various solvent fractions of fine ginseng root. Food Sci Biotechnol 18(2):513-518.

76. Nguyen CT, Luong TT, Lee SY, Kim GL, Kwon H, Lee HG, Park CK, Rhee DK (2015). Panax ginseng aqueous extract prevents pneumococcal sepsis in vivo by potentiating cell survival and diminishing inflammation. Phytomedicine 22(11):1055-1061. doi: 10.1016/j.phymed.2015.07.005

77. Ahn JY, Choi IS, Shim JY, Yun EK, Yun YS, Jeong G, Song JY (2006). The immunomodulator ginsan induces resistance to experimental sepsis by inhibiting Toll-like receptor-mediated inflammatory signals. Eur J Immunol 36(1):37-45. doi: 10.1002/eji.200535138 